\title{
APLIKASI SISTEM INFORMASI PEMBELIAN DAN PENJUALAN PERALATAN OLAHRAGA PADA INDO JAYA SPORT BERBASIS JAVA
}

\author{
Oky Muhammad Sujatmiko ${ }^{1}$, Bondan Dwi Hatmoko ${ }^{2}$, Luh putu Widya Adnyani ${ }^{3}$ \\ ${ }^{1}$ Informatika, Fakultas Teknik Dan Ilmu Komputer, Universitas Indraprasta PGRI \\ oky.msuja@gmail.com*
}

\begin{abstract}
The sales transaction process at Indo Jaya Sport is still done manually. Records of procurement and sales are applied to the ledger. Problems that often occur such as storage and repetition of unstable data and the process of human error in data collection and difficulties in the process of making reports, especially sales reports. The research objective is to build an information system for buying and selling sports equipment that can help and simplify store activities in carrying out computerized purchase and sales transaction processes to minimize human error at Indo Jaya Sport stores. The author is interesting that the application information system created for the Indo Jaya Sport store provides a buying and selling process, both purchases from suppliers and sales to customers as well as purchasing and sales reports to be more precise and accurate.
\end{abstract}

Keywords: Application, System Information, MySQL

\begin{abstract}
Abstrak
Proses transaksi penjualan pada Indo Jaya Sport masih dilakukan secara manual. Pencatatan pengadaan barang dan penjualan diterapkan pada buku besar. Permasalahan yang sering terjadi seperti penyimpanan dan pengulangan data yang kurang stabil serta human errordalam proses pendataan serta kesulitan dalam proses pembuatan laporan terutama laporan penjualan. Tujuan penelitian adalah untuk membangun sistem informasi pembelian dan penjualan peralatan olahraga yang dapat membantu dan mempermudah aktifitas toko dalam melakukan proses melakukan transaksi pembelian dan penjualan yang terkomputerisasi untuk meminimalisir human error pada toko Indo Jaya Sport. Penulis menarik kesimpulan bahwa sistem informasi aplikasi yang dibuat untuk toko Indo Jaya Sport memberikan kemudahan dalam proses pembelian dan penjualan baik pembelian dari supplier dan penjualan ke pelanggan serta laporan pembelian dan penjualan menjadi lebih tepat dan akurat.
\end{abstract}

Kata Kunci: Aplikasi, Sistem Informasi, MySQL

\section{Pendahuluan}

Dalam perkembangan dunia teknologi pada saat ini teknologi informasi berkembang dengan sangat pesat. Kehadiran komputer di tengah-tengah aktivitas bagi kalangan bisnis, merupakan salah satu alternatif dalam mengatasi permasalahan-permasalahan yang makin sering terjadi dan untuk meningkatkan efektifitas serta efisiensi. sistem informasi sangat berpengaruh disegala bidang kehidupan baik di bidang politik, pendidikan, maupun ekonomi, khususnya dibidang perdagangan. Salah satu dari kemajuan sistem informasi yang kita kenal sekarang ini adalah sistem penyimpanannya, Dimana sistem penyimpanan data sangat membantu dalam suatu usaha perdagangan, seperti penyimpanan data barang pada toko tersebut. Keberhasilan suatu perusahaan pada umumnya dapat dilihat dari kemampuan perusahaan dalam memperoleh laba. Perusahaan dapat meningkatkan jumlah modal serta dapat mengembangkan dan memperluas bidang usahanya. Untuk mencapai tujuan tersebut, perusahaan memprioritaskan kegiatan dalam bentuk penjualan untuk memperoleh laba, semakin besar volume penjualan maka semakin besar pula laba yang diperoleh.
Pada proses penjualan peralatan olahraga ini pelanggan melakukan permintaan barang kepada kasir, setelah melakukan permintaan kemudian kasir mengecek barang yang dibutuhkan tersedia atau tidak, disini sering terjadi kesalahan dalam perhitungan stock barang jika barang tersedia maka akan segara diproses untuk diberikan kepada pelanggan dan pelanggan melakukan pembayaran. Hasil pembelian dan penjualan akan dibuatkan laporan setiap bulan yang akan diserahkan kepada pemimpin. Dalam proses pembuatan laporan masih terjadi kesulitan seperti, keterlambatan waktu, sulit mengumpulkan laporan pada bulan-bulan sebelumnya.

\subsection{Aplikasi}

Aplikasi adalah penggunaan dalam suatu komputer, instruksi (instructiom) atau pernyataan (statement) yang disusun sedemikian rupa sehingga komputer dapat memproses input menjadi output [1].

\subsection{Sistem}

Sistem adalah kumpulan dari elemen-elemen yang berinteraksi untuk mencapai suatu ujuan tertentu. Sistem ini menggambarkan suatu kejadian-kejadian yang nyata 
adalah suatu obyek nyata, seperti tempat, benda, dan mengembangkan teori di mana pengumpulan data dan orang-orang yang betul-betul ada dan terjadi [2]. analisa berjalan pada waktu yang bersamaan [5].

\subsection{Informasi}

informasi adalah data yang telah diolah menjadi suatu bentuk yang penting bagi si penerima dan mempunyai nilai nyata atau yang dapat dirasakan dalam keputusankeputusan yang sekarang atau keputusan-keputusan yang akan datang [3].

\subsection{Pembelian dan Penjualan}

Pembelian merupakan kegiatan utama untuk menjamin kelancaran transaksi penjualan yang terjadi dalam suatu perusahaan. Dengan adanya pembelian, perusahaan dapat secara mudah menyediakan sumber daya yang diperlukan organisasi secara efisien dan efektif. Pembelian adalah akun yang digunakan untuk mencatat semua pembelian barang dagang dalam satu periode [4].

Penjualan merupakan salah satu fungsi pemasaran yang sangat penting dan menentukan bagi perusahaan dalam mencapai tujuan perusahaan yaitu memperoleh laba untuk menjaga kelangsungan hidup perusahaan. Sebenarnya pengertian penjualan sangat luas, dalam buku kamus istilah ekonomi menyatakan bahwa penjualan adalah suatu kegiatan yang ditujukan untuk mencari pembeli, mempengaruhi dan memberi petunjukagar pembeli dapat menyesuaikan kebutuhannya. Penjualan merupakan proses dimana kebutuhan pembeli dan kebutuhan penjual dipenuhi, melalui antar pertukaran informasi dan kepentingan [4].

Tujuan penelitian ini yaiutu membuat rancang bangun sebuah sistem informasi penjualan yang terkomputerisasi untuk membuat sistem pendataan penjualan yang akurat dan mengindari Human error.Metode Penelitian

\section{Metode Penelitian}

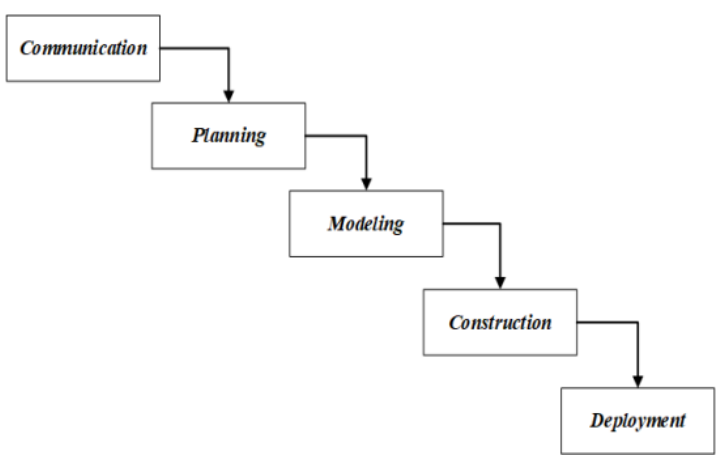

Gambar 1. Metode Waterfall

Dalam penelitian ini penulis menggunakan metode grounded research sebagai metode penelitian waterfall adalah suatu metode penelitian yang mendasarkan diri kepada fakta dan menggunakan analisa perbandingan bertujuan untuk mengadakan generalisasi empiris, menerapkan konsep-konsep, membuktikan teori dan
Metode Pengumpulan data yang digunakan oleh penulis ada beberapa cara sebagai berikut:

\subsection{Studi Lapangan}

a. Wawancara

Teknik ini digunakan untuk mengumpulkan data dan informasi yang berkaitan dengan administrasi pembelian dan penjualan. Melakukan penelitian yang berupa tanya jawab dengan pihak toko secara langsung.

b. Observasi

Observasi dilakukan dalam penguumpulan data untuk menunjang penelitian secara keseluruhan, pengamatan sistem yang sedang berjalan dilakukan di toko Indo Jaya Sport yang berkaitan dengan judul skripsi/tugas akhir.

\subsection{Studi Pustaka}

a. Internet

Browsing internet adalah teknik pengumpulan data atau informasi yang didapat dari situs yang berhubungan dengan sistem laporan hasil pemikiran yang dibutuhkan. Referensi melalui browsing di internet yang ada hubungannya dengan perancangan sistem Pembelian dan Penjualan peralatan olahraga di Indo Jaya Sport.

b. Studi Kepustakaan

Penulis juga melakukan metode kepustakaan, yaitu dengan membaca buku-buku yang berhubungan dengan judul skripsi sebagai bahan referensi bagi penulis, sumber yangg penulis dapatkan bersumber dari buku-buku, seperti: Java, MySQL dan buku skripsi yang ada di Universitas Indraprasta PGRI. Serta data dan dokumen yang berasal dari Toko Indo Jaya Sport yang dapat menunjang dalam penulisan tugas akhir ini.

Adapun metode pengembangan sistem yang digunakan dalam penelitian ini adalah SDLC (System Development Life-Cycle) dengan teknik waterfall yang terdiri dari 5 tahapan, antara lain: Communication, Planning, Modeling, Construction, Deployment

\subsubsection{Communication}

Sebelum memulai pekerjaan yang bersifat teknis, sangat diperlukan adanya komunikasi dengan customer demi memahami dan mencapai tujuan yang ingin dicapai. Hasil dari komunikasi tersebut adalah inisialisasi proyek seperti menganalisis permasalahan yang dihadapi dan mengumpulkan data-data yang diperlukan, serta membantu mendefinisikan fitur dan fungsi dari aplikasi. Pengumpulan data-data tambahan bisa juga diambil dari jurnal, artikel, paper dan internet.

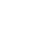




\subsubsection{Planning}

Tahap berikutnya adalah tahapan perencanaan yang menjelaskan tentang estimasi tugas-tugas teknis yang akan dilakukan, risiko-risiko yang dapat terjadi, sumber daya yang diperlukan dalam membuat sistem, produk kerja yang ingin dihasilkan, penjadwalan kerja yang akan dilaksanakan, dan tracking proses pengerjaan sistem.

\subsubsection{Modeling}

Tahapan ini adalah tahap perancangan dan pemodelan arsitektur sistem yang berfokus pada perancangan struktur data, arsitektur software, tampilan interface, dan algoritma program. Tujuannya untuk lebih memahami gambaran besar dari apa yang akan dikerjakan.

\subsubsection{Construction}

Tahapan ini merupakan proses penerjemahan bentuk desain menjadi kode atau bentuk bahasa yang dapat dibaca oleh mesin. Setelah pengkodean selesai, dilakukan pengujian terhadap sistem dan juga kode yang sudah dibuat. Tujuannya untuk menemukan kesalahan yang mungkin terjadi untuk nantinya diperbaiki.

\subsubsection{Deployment}

Tahapan terakhir ini merupakan tahapan implementasi software ke customer, perbaikan software, evaluasi software, dan pengembangan software berdasarkan umpan balik yang diberikan agar sistem dapat tetap berjalan dan berkembang sesuai dengan fungsinya.

\section{Hasil dan Pembahasan}

\subsection{Diagram Alir Data}

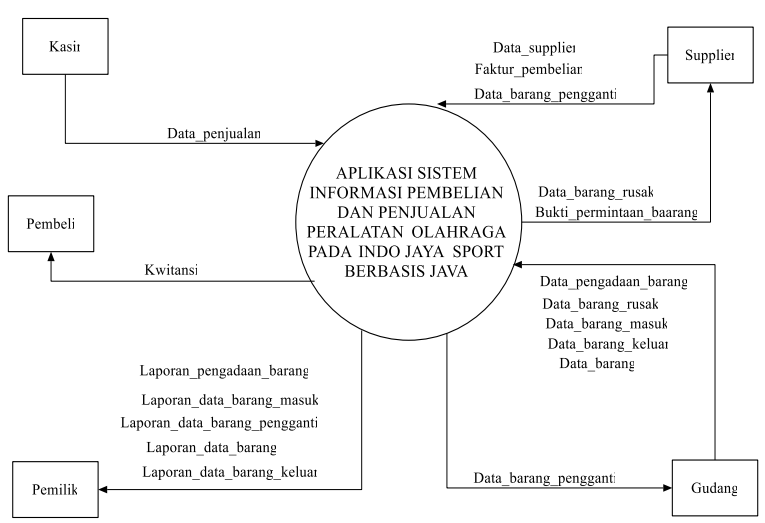

Gambar 2. Diagram Alir Data

Diagram Alir Data/Data Flow Diagram adalah suatu model logika data atau proses yang dibuat lebih mendetail dibanding diagram konteks yang diperbolehkan, bisa dicapai dengan mengembangkan diagram. Sisa diagram asli dikembangkan ke dalam gambaran yang lebih terperinci yang melibatkan tiga sampai Sembilan proses dan menunjukkan penyimpanan data dan aliran data baru pada level yang lebih rendah [6].

Diagram alir data menunjukan bahwa:
1. Proses Pendataan Supplier

Merupakan data supplier yang diberikan lepada bagian gudang. Data tersebut merupkan keseluruhan data supplier.

2. Proses Pendataan Pembelian

Proses ini dilakukan oleh bagian gudang, Melakukan pendataan barang yang dibeli dari supplier.

3. Pendataan Barang Pengganti

Merupakan pendataan barang rusak yang sudah diganti oleh supplier.

4. Pendataan Barang

Bagian gudang melakukan perhitungan barang lalu menginput data barang.

5. Pendataan Penjualan

Pendataan penjualan dilakukan oleh bagian kasir jika ada transaksi kasir menghitung barang yang dijual lalu melakukan input data penjualan.

\subsection{Normalisasi}

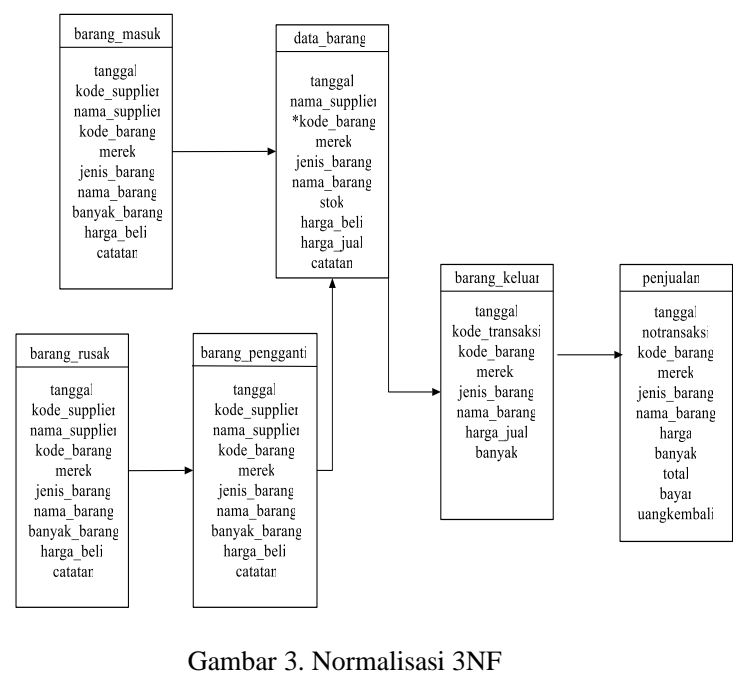

Normalisasi merupakan proses pengelompokan elemen data menjadi tabel-tabel yang menunjukan entitas dan relasinya [7]. 


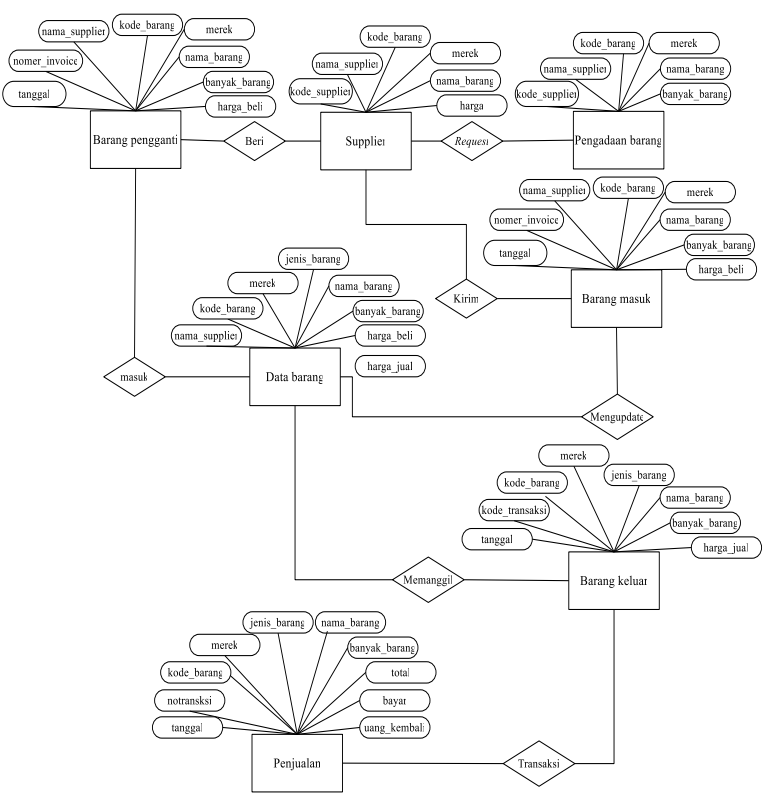

Gambar 4. ERD (Entity Relationship Diagram)

Entity Relationship Diagram (ERD) adalah sekumpulan cara atau peralatan untuk mendeskripsikan data-data atau objek-objek yang dibuat berdasarkan dan berasal dari dunia nyata yang disebut entitas (entity) serta hubungan (relationship) antar entitas-entitas tersebut dengan menggunakan beberapa notasi [8].

\subsection{Software Pendukung Pembuatan Aplikasi}

Aplikasi pembelian dan penjualan ini digunakan menggunakan bahasa pemrograman java. JAVA adalah bahasa pemrograman yang dapat dijalankan di berbagai komputer termasuk telepon genggam

(Cellular). Bahasa ini awalnya dibuat oleh James Gosling saat masih bergabung di Sun Microsystems saat ini merupakan bagian dari Oracle dan dirilis tahun 1995. Bahasa ini banyak mengadopsi sintaksis yang terdapat pada $\mathrm{C}$ dan $\mathrm{C}++$ namun dengan sintaksis model objek yang lebih sederhana serta dukungan rutin-rutin aras bawah yang minimal [9].

Aplikasi ini didukung dengan Database MySQL, MySQL adalah program database server yang mampu menerima dan mengirimkan data dengan sangat cepat, multi user serta menggunakan peritah standar SQL (Structured Query Language) dan baik digunakan sebagai client maupun server [10].

\subsection{Tujuan Perancangan Aplikasi}

Tujuan Perancangan Aplikasi ini antara lain:

1. Membuat sistem teraplikasi pada proses pembelian dan penjualan yang dapat dengan mudah digunakan oleh pegawai.

2. Membuat Sistem untuk transaksi pembelian dan penjualan dengan mengembangkan sistem yang sudah ada.
3. Membantu menyajikan laporan pembelian dan penjualan yang baik serta terkomputerisasi.

\subsection{Gambaran Umum}

Dengan di buatkannya Aplikasi Sistem Informasi Pembelian Dan Penjualan Peralatan Olahraga Pada Indo Jaya Berbasis Java menjadi salah satu sistem yang baru pada proses transaksi pengadaan dan penjualan barang, dengan pengubah cara pengolahan data yang sebelumnya dikerjakan secara manual menjadi teraplikasi atau terkomputerisasi. Dengan adanya aplikasi pembelian dan penjualan tersebut diharapkan dapat memberikan kemudahan kepada penggunanya dan mampu memberikan informasi mudah serta lebih efektif dan efisien, sehingga proses pengolahan transaksi dapat dilakukan dengan mudah serta dapat meningkatkan kinerja karyawan.

\subsection{Implementasi Perangkat Lunak}

Perangkat lunak yang digunakan pada sistem computer yang digunakan untuk membangun Aplikasi: sebagai berikut:

1. Bahasa Pemrograman Java Dalam hal ini digunakan Java Development Kit (JDK) 8 dan Java Runtime Environment (JRE).

2. NetBeans IDE 8.2

3. Database MySQL

4. Operating System Windows 10

5. XAMPP server untuk local internet dan penyimpana database.

6. ClickCharts Professional by NCH Software untuk perancangan tampilan aplikasi penggajian.

\subsection{Tampilan Layar Input Dan Output}

\subsubsection{Tampilan Layar Menu Utama}

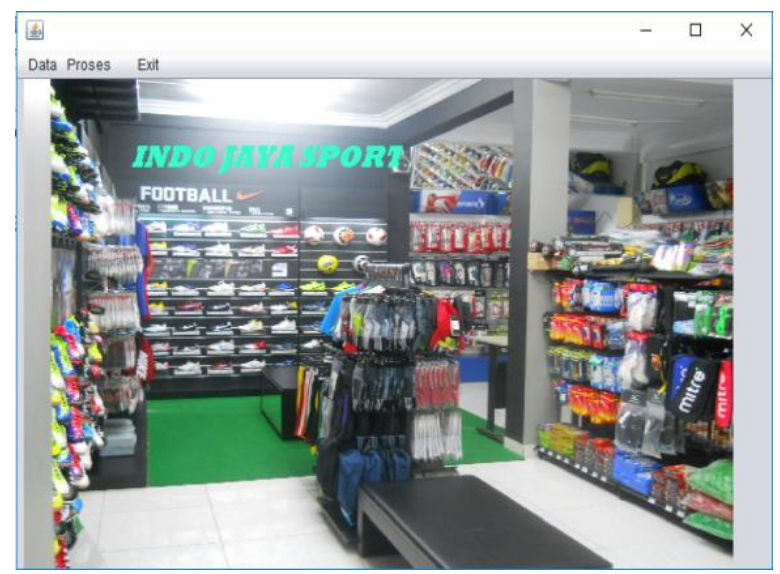

Gambar 5. Perancangan Layar Menu Utama

Berikut ini merupakan penjelasan mengenai fitur-fitur yang ada pada aplikasi penggajian. Fitur-fitur tersebut antara lain sebagai berikut:

1. Mampu mengelola sistem aplikasi pembelian dan penjualan yang mudah dimengerti dan dapat 
dimanfaatkan untuk membantu pengolahan data- Perancangan input pengadaan barang ini merupakan data. inputan untuk melakukan pemesanan barang kepada

2. Mampu menjalankan sistem yang bisa supplier. mengerjakan proes transaksi secara terintegrasi.

3. Mampu mengelola sistem aplikasi pembelian dan 3.8.4. Perancangan Output penjualan yang mudah dimengerti dan dapat dimanfaatkan untuk membantu pengolahan datadata.

4. Mampu menjalankan sistem yang bisa mengerjakan proes transaksi secara terintegrasi.

5. Mampu menghasilkan informasi laporan pengadaan dan penjualan barang secara detail dan konkrit. Sehingga pemilik toko dapat dengan mudah melakukan evaluasi.

\subsubsection{Tampilan Input Menu Transaksi Penjualan}
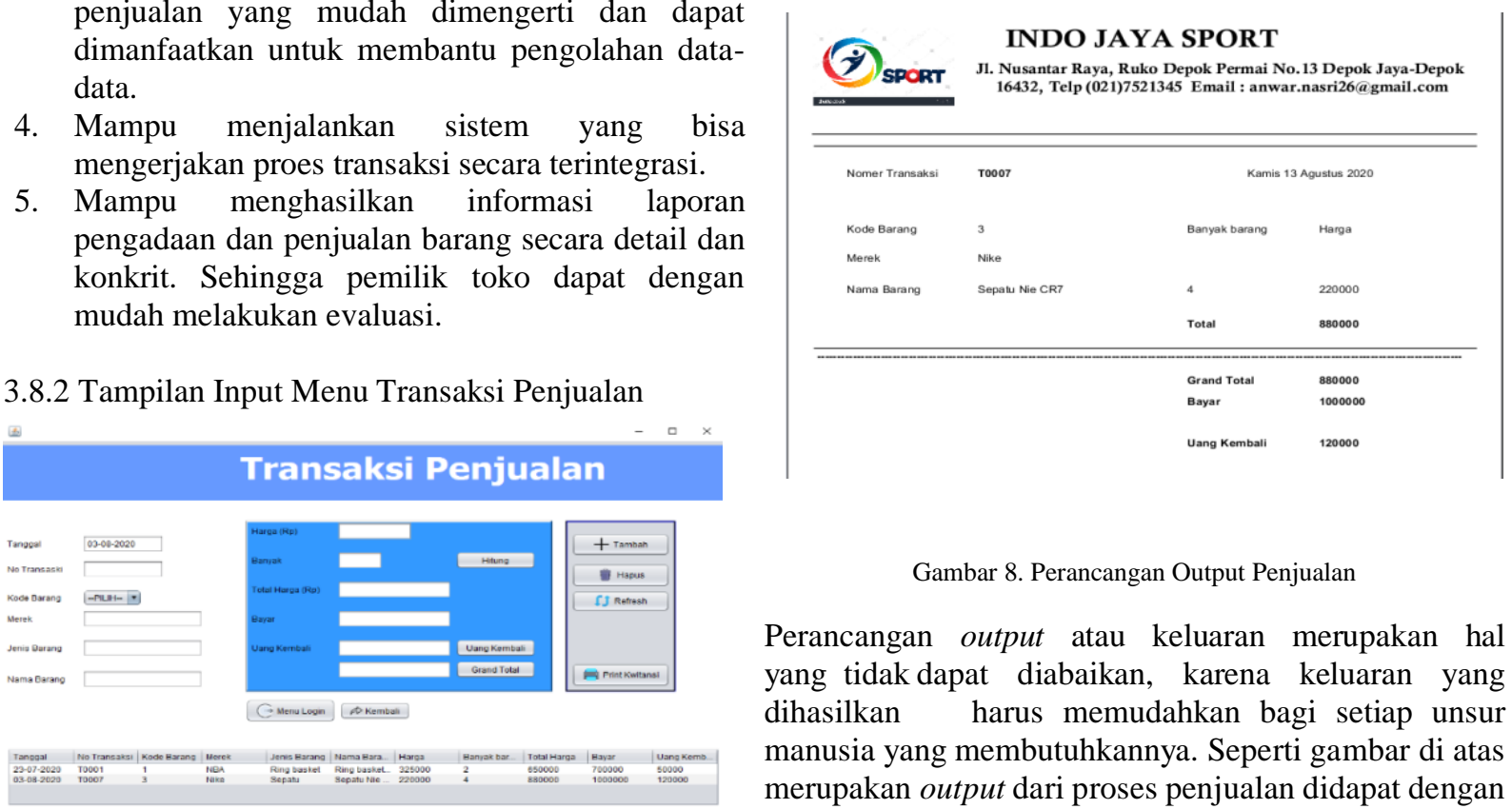

Gambar 8. Perancangan Output Penjualan

Perancangan output atau keluaran merupakan hal yang tidak dapat diabaikan, karena keluaran yang dihasilkan harus memudahkan bagi setiap unsur manusia yang membutuhkannya. Seperti gambar di atas merupakan output dari proses penjualan didapat dengan melakukan input pada proses penjualan terlebih dahulu sehingga bisa dilakukan print out dari proses penjualan yang berupa kwitansi sebagai bukti penjualan barang.

Gambar 6. Perancangan Input Pada Menu Transaksi Penjualan

\section{Kesimpulan}

Perancangan input merupakan rancangan yang menggambarkan form input suatu data pada proses transaksi. Gambar di atas ini merupakan bagian input data pada aplikasi penjualan.

\subsubsection{Tampilan Input Pada Menu Pengadaan Barang}

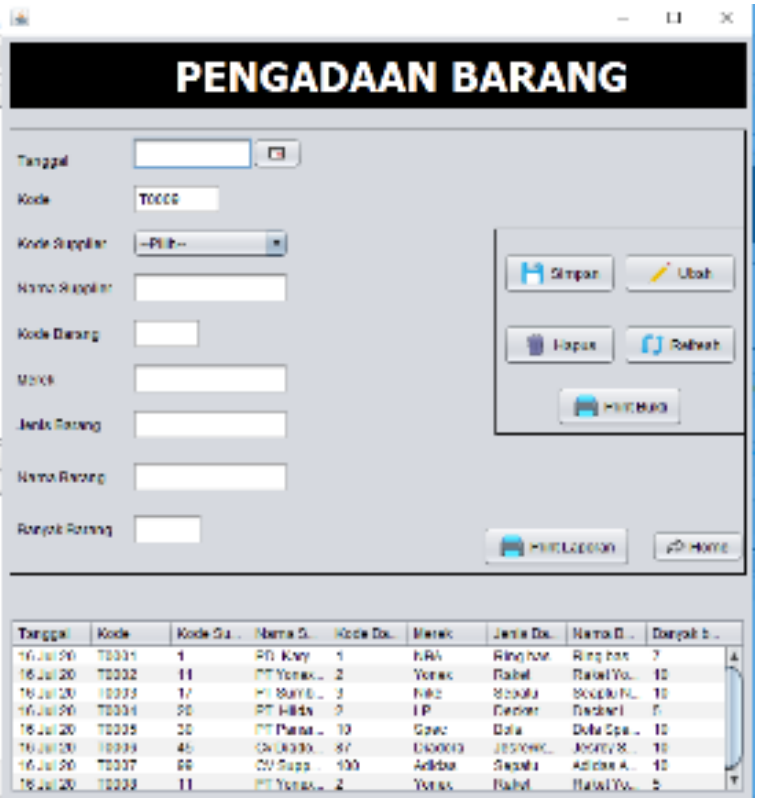

Adapun kesimpulan yang diperoleh darihasil analisa yang didapatkan terhadap data pengujian adalah sebagai berikut:

1. Dengan adanya program aplikasi pembelian dan penjualan pada Indo Jaya Sport, proses pencatatan atau pendataan pembelian dan penjualan dapat dilakukan secara teraplikasi mempermudah karyawan dalam melakukan pendataan sehingga mengurangi human error.

2. Dengan dibuatkannya aplikasi ini dapat menjadi salah satu cara dalam pembaruan sistem yang sudah ada pada Toko Indo Jaya Sport terutama pada proses penjualan. Selain mempermudah dalam prosesnya juga dapat memenuhi sarana dan prasarana di toko, serta dapat menunjang kemajuan sistem pada toko tersebut. Tidak hanya mempermudah dalam proses pengolahan data penjualan saja, dengan adanya aplikasi maka keamanan data-data penjualan dapat terjaga.

3. Dengan aplikasi ini dapat memudahkan bagian kasir dalam pembuatan laporan transaksi penjualan.

4. Dengan adanya aplikasi ini juga dapat memudahkan bagian gudang dalam melakukan pengadaan barang. 


\section{Daftar Rujukan}

[1] H. Abdurahman, A. R. Riswaya, and A. Id, "Aplikasi Pinjaman Pembayaran Secara Kredit Pada Bank Yudha BHakti," Apl. Pinjaman Pembayaran Secara Kredit Pada Bank Yudha BHakti, vol. 8, no. 2, pp. 61-69, 2014.

[2] M. L. Harumy, T.H.F., Julham Sitorus, "Sistem Informasi Absensi Pada Pt . Cospar Sentosa Jaya Menggunakan Bahasa Pemprograman Java," J. Tek. Informartika, vol. 5, no. 1, pp. 63-70, 2018.

[3] Y. J. Syafitri, "Perancangan Sistem Informasi Pemesanan Obat Menggunakan Bahasa Pemrograman Berorientasi Objek," KomTekInfo, vol. 4, no. 1, pp. 2128, 2013.

[4] M. Abdurahman, "Sistem Informasi Pengolahan Data Pembelian Dan Penjualan Pada Toko Koloncucu Ternate," IJIS - Indones. J. Inf. Syst., vol. 2, no. 1, 2017 , doi: 10.36549/ijis.v2i1.22.

[5] A. Pada, P. T. Sumber, and M. Kencana, "Perancangan Aplikasi Manajemen Purchase Order," vol. 01, no. 02, pp. 266-273, 2020.

[6] D. A. Rivai and B. E. Purnama, "Pembangunan Sistem Informasi Pengolahan Data Nilai Siswa Berbasis Web Pada Sekolah Menengah Kejuruan (SMK) Miftahul Huda Ngadirojo," Indones. J. Netw. Secur., vol. 3, no. 2, pp. 2302-5700, 2015.

[7] A. Mubarok and S. Hadianti, "Perancangan Program Transaksi Penerimaan Dan Pengeluaran Kas Berbasis Web," J. Inform., vol. III, no. 1, p. 8, 2016.

[8] H. Toba and M. Fransisca, "Perancangan dan Pembuatan Sistem Pakar Berbasis Runut Maju untuk Diagnosa Awal Perkembangan Emosi pada Anak," J. Inform., vol. 5, no. 1, pp. 1-13, 2012.

[9] M. Metode Blowfish Dengan Bahasa Pemrograman Java Mohamad Natsir, K. Kunci, K. Simetris, and A. Blowfish, "Pengembangan Prototype Sistem Kriptografi Untuk Enkripsi Dan Dekripsi Data Office," Jurnal, vol. 6, pp. 2089-5615, 2016.

[10] E. Usada, Y. Yuniarsyah, and N. Rifani, "Rancang Bangun Sistem Informasi Jadwal Perkuliahan Berbasis Jquery Mobile Dengan Menggunakan PHP Dan MySQL," J. INFOTEL - Inform. Telekomun. Elektron., vol. 4, no. 2, p. 40, 2012, doi: 10.20895/infotel.v4i2.107. 